nimbus clouds, for example-are subgrid scale in size and their important contribution to the working of the atmosphere needs investigating. The third concerns the selection of the mathematical methods of integration, where there will be a delicate balance between accuracy and economy.

An additional complication is the problem of predictability which is currently exercising meteorologists. It is the problem of determining for how long ahead useful forecasts can be made. It is generally agreed that the limit is less than one month and more than five or six days, using current mathematical models and the meteorological observations presently available. Experimental determination of the limit by integration of the model equation is very difficult because a few integrations cannot give results representative of so variable a fluid as the atmosphere, while each integration predicting for, say, 14-20 days, is extremely costly. Experiments carried out up to date show that there is value in the forecasts up to ten days and this is confirmed by the few integrations carried out at the Centre. The Centre will cooperate as fully as it can in the First GARP Global Experiment, which is designed, among other objectives, to determine the limit of predictability.

With the aid of computer programmes for atmospheric models provided by the Geophysical Fluid Dynamics Laboratory of Princeton, the Department of Meteorology, UCLA, and the UK Meteorological Office, this research has already started. Ten days forecasts have already been made with these models, using both a CDC 6600 computer installed for the Centre's use by CDL in Bracknell and the UK Meteorological Office computer complex; their production is regarded as a familiarisation exercise.

A considerable effort must also be devoted to the selection and installation of suitable computing facilities; speeds of 50 million instructions per second are only just being developed and the selection of an integrated system capable of carrying out the data processing and the number-crunching on an operational basis will certainly present difficulties. Of course, the system must be available before 1980 since the Centre will need to develop its operational programmes on it.

Europe, through the member nations, has created the first scientific centre for the study and preparation of medium range weather forecasts. The international meteorological community has expressed great interest in this new venture with offers of help and cooperation. Already a cooperative agreement has been signed with the World Meteorological Organisation and the provision of computer programmes is one example of the help that has been made available. Nevertheless the Director and his staff face a difficult task in attempting to build up a new international scientific centre in a time of recession.

\title{
Science vs. the public
}

Colin Norman reports from Cambridge, Massachusetts, where attempts are being made to restrict recombinant $D N A$ research.

IN a move which establishes a virtually unprecedented degree of community control over an area of scientific research, the city council of Cambridge, Massachusetts, last week passed a resolution calling for a three-month moratorium on certain types of recombinant DNA research at Harvard and Massachusetts Institute of Technology. Though the moratorium will have little immediate impact, since experiments of the types outlawed by the council are not yet being conducted at either university, the council's actions could have broad and lasting implications.

While the moratorium is in effect, a special review board, also established by the council last week, will draw up recommendations to control recombinant DNA research in Cambridge. In addition the board has been given the astonishing task of reviewing all laboratory experiments in the city, to ensure that none of them poses a threat to public health.

The council's actions are the result of a bitter clash between groups of scientists, city officials and Cambridge residents over plans to conduct recombinant DNA research at Harvard and MIT. The dispute, which centres on the question of whether or not such experiments can be carried out safely, has been a bloody battle which has provided ample evidence of public distrust of scientists and which has further damaged the already abysmal relationships between the city and its two famous universities.

In a sense, the clash has also provided the first real test of public acceptability of federal safety guidelines governing recombinant DNA research issued last month by the National Institutes of Health (NIH) (see Nature, July 1). The guidelines were developed mostly by scentists, and have not previously been subjected to the intense public scrutiny now being lavished on them in Cambridge. Those who support the guidelines-and they include the vast majority of the scientific community-can take little comfort from the public debate in Cambridge. Moreover, many scientists are worried that similar clashes could break out elsewhere, a development which the Mayor of Cambridge has been doing his best to promote by trying to interest his fellow mayors in the issue.

The hostilities stem originally from a proposal, put forward two years ago by a group of scientists headed by Mark Ptashne, to convert some rooms on the fourth floor of the Harvard Biological Laboratories into a special safety facility. Designed primarily for experiments with the animal virus SV40-experiments which are frequently carried out in other institutions under much less stringent safety conditions - the facility became a major focus of controversy when the plans were modified to include space for some recombinant DNA work.
At present, Harvard researchers are restricted to experiments, judged by those who wrote the guidelines to entail little risk, which do not require special safety facilities. According to Matthew Meselson, Chairman of the Department of Biochemistry and Molecular Biology, about 30 people at Harvard are now working, at various levels, on such experiments. Construction of the safety laboratory-a moderate containment, or P3, facility under the NIH guidelines-would allow many other types of experiments to be undertaken at Harvard.

Opposition to the facility came first from scientists at Harvard. It took two forms. Some argued that although recombinant DNA research is an exciting and potentially revolutionary area of research which should be conducted at a major research institute like Harvard, the building housing the biological laboratories is unsuitable for a safety facility. It is old, infested with ants and cockroaches, and situated in a densely populated area. The second, more fundamental objection came from scientists who argued that recombinant DNA research is inherently so risky that virtually all such experiments should be confined initially to one or two specially equipped national facilities, or be outlawed entirely, until the hazards are better defined.

In spite of the intensity of the opposition construction of the facility has been approved in principle by a special biohazards committee, by Harvard's top-level committee on research policy, and by the Dean of Arts and Sciences. Final plans for the lab are now being drafted. 
The internal dispute at the university spilled over into the city and mushroomed into a major political issue early last month when the matter was reported at length in the Boston Phoenix, a weekly area newspaper. At that point, Cambridge city Mayor Alfred E. Vellucci stepped in. An irascible, colourful, shrewd politician with 26 years' service on the council, Vellucci is no friend of Harvard or MIT. In fact, the strained relationships between town and gown in the city provide an important backdrop to the clash over recombinant DNA research in the city.

A major source of irritation is the fact that the two large, wealthy universities are situated in a predominantly industrial community and are exempt from paying many city taxes. There have also been problems over pressure on city housing-" "If it gets any worse", Vellucci said in an interview last week, "we'll have to knock down some buildings for somewhere for people to live". A good example of town-gown friction came a few years ago when the city council passed a resolution, introduced by Vellucci, to pave over Harvard Yard and turn it into a parking lot. (The resolution, according to Vellucci, successfully spurred the universities into building more student parking facilities.)

Vellucci's dignity was pricked when he read in the Phoenix that Harvard scientists were planning to conduct reportedly dangerous experiments without first consulting city officials. And his belief in the dangers of the experiments was heightened by a visit from George Wald, a Nobel prizewinner and a vigorous opponent of the plans for the laboratory. Vellucci called a council meeting for June 23-ironically the day on which NIH issued its guidelines-to discuss the matter. The meeting provided a forum for a bitter clash between mostly radical scientists and their more establishment colleagues, with council members often bewildered and Mayor Vellucci enjoying the publicity, and especially enjoying the opportunity to haul Harvard intellectuals over the coals.

At one point in the proceedings, Vellucci particularly chastised Daniel Branton, chairman of the biohazards committee, for making little attempt to bring city officials into the discussions of plans for the safety laboratory. Branton protested that he had, but Vellucci scored a major debating point.

During the meeting, Vellucci proposed a resolution calling for a twoyear moratorium on all recombinant DNA research in the city-even those experiments already under way which are judged to entail little risk. No vote was taken at that meeting, however, and it was adjourned after some five hours of bitter exchanges.

The next day, Vellucci issued a public statement declaring that the meeting "has made it clear to me that a 'cooling off' period is necessary in order for the mayor and the council to deal with this matter in a calm and rational way". He then softened his proposal for a two-year moratorium, calling instead for a three-month 'good faith' halt to the research "so that all concerned can properly review relevant testimony. He later offered another proposal to establish a review board to look into the issue and to examine other research programs at Harvard and MIT to see whether any pose a potential public health risk. A second council meeting was called on July 7 to resume testimony and to discuss the resolutions.

In the fortnight between the meetings, some councillors and the mayor spent a good deal of time contacting, and being contacted by, scientists. As a result, Vellucci announced to the meeting last week that he had "learned enough about recombinant DNA molecules in the last two weeks to take on all the Nohel prizewinners in the city of Cambridge". He has certainly taken on most of them.

The meeting began with a demonstration of techniques used in microbiology, for the councillors' edification. Meselson then described the formulation of the NIH guidelines, noting that in each new draft they were made more strict. And William Gartland, Director of the newly created NIH Recombinant DNA Activity Unit, described the guidelines themselves, pointing out in particular the contrast with the situation in the United Kingdom, where the whole business of setting regulations on the research is taking place behind closed doors.

At that stage, Councillor David Clem. a young, articulate council member who has obviously done his homework on the issue, proposed a number of amendments to Vellucci's resoultions. The most important change was an amendment to limit the moratorium to research requiring $\mathrm{P} 3$ and $\mathrm{P} 4$ facilities, according to the NIH guidelines. That amendment was accepted without debate, even though it meant the difference between stopping several experiments and stopping nothing.

Harvard has no P3 or P4 facility, so no such experiments are going on there. MIT, however, has a P3 facility in the Center for Cancer Rescarch, but no P3 level experiments have yet been initiated. One experiment is being planned at the facility by Dr Philip Sharp, however. He said last week that he has been holding off on the researchwhich would involve inserting mammalian genes into $E$. coli-until the
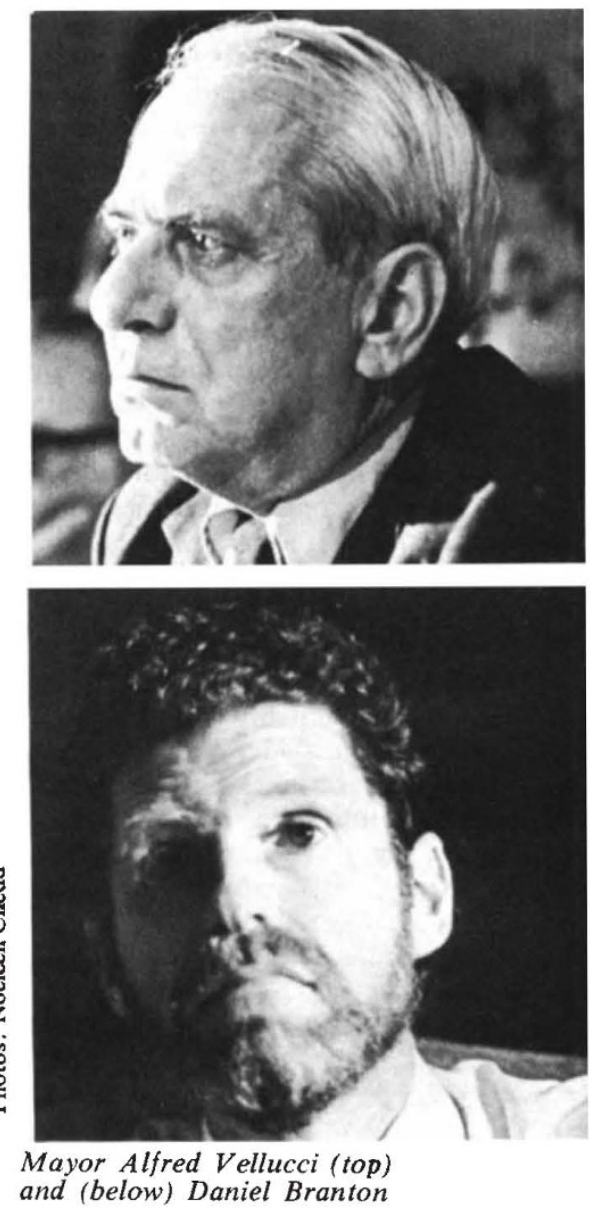

NIH guidelines had been published, and that it would take at least three morsths to get the experiment approved and under way.

Another council member, Sandra Graham, then proposed that the moratorium should be extended from three months to six. After some debate, the amendment was defeated by six votes to two. Vellucci then proposed that the moratorium should be extended to two years if no agreement has been reached at the end of three months. That was also defeated by six votes to two. At that point, the resolution with Clem's amendment was approved by five votes to four.

The second resolution, establishing a Cambridge Laboratory Experimentation Review Board, was then voted on, and similarly approved by five votes to four.

With the amended resolutions approved further testimony on them became superfluous but it was taken anyway-until 12.45 am-with the council chamber packed with scientists and with people from both sides heatedly stating their views.

A number of interviews with scientists the day after the meeting demonstrated that both sides are relatively pleased with the outcome so far. Proponents of the research are happy that the moratorium will do no damage to current research and that it 
is much less restrictive than the original resolutions. And opponents of the research are pleased that the vote has established the principle of community control over scientific research.

There is, however, considerable unease within the scientific community, and with good reason. The council meeting secured a precarious ceasefire, which could easily erupt into renewed hostilities. An important factor in what happens next will be the work of the experimentation review board. Its terms of reference are broad and hazy, and its members are yet to be appointed. One potential member is George Wald, who was asked by Vellucci last week whether he would serve if asked and replied that he would be "happy and honoured to do so". Vellucci said after the meeting that the board would contain both supporters and opponents of the research and that some city residents would also be included. If necessary, he said, he would lock them all into a room and not let them out until they have come to an agreement.
Creation of the board has at least taken the council out of its uncomfortable position in the middle of the dispute. But if the board has not reached agreement at the end of three months, the council will be thrown right back in and there would then be a possibility that the moratorium would be lengthened and, perhaps, broadened. Alternatively, if the board vigorously pursues its mandate to look into all laboratory work in Cambridge, there is a danger that it could turn into a public witch hunt. "We will be keeping our fingers crossed in the next three months," says Richard Leahy, a dean in the Faculty of Arts and Sciences.

On the other hand, creation of the review board at least establishes a long-needed channel of communication between the university scientists and the city. It could provide an important vehicle for informing and educating the people of Cambridge about recombinant DNA research and about the process which led to adoption of the NIH guidelines. It is conceivable that it could even help smooth some of the causes of town-gown friction.

Another possibility which is clearly worrying people far removed from Cambridge is that similar clashes could erupt in other cities. In that respect, Vellucci has been active. Last month he attended a meeting of the United States Conference of Mayors armed with a resolution stating that "no university or institution may begin recombinant DNA experiments without first notifying the mayor of the city or town in which the experimentation will take place. Thereupon, the mayor and legislative body shall call a public hearing so that the public may be an active participant in the decision-making process". The resolution was referred to a committee for consideration, and Vellucci said last week that he intends to press the matter at future meetings.

It is possible that the dispute in Cambridge will now quietly die away. But with so many articulate and politically motivated scientists opposed to the research there, the prospects at this stage are far from certain. The next few months will be critical.

\section{JRC programme awaits approval}

The Commission of the EEC has circulated final proposals for the next multiannual research programme of the Joint Research Centre. These now await ratification from the Council of Ministers. Chris Sherwell reports

THE multiannual research programme of the European Community's Joint Research Centre (JRC) for the four years beginning in January 1977, the final detailed proposals for which were submitted by the Commission to the Council of Ministers some two weeks ahead of the Council's May 24 meeting, may not be approved before September, even though preliminary discussions of the overall framework for the Community's 1977 budget are due to start later this month.

The Council decided at the May meeting to consult both the European Parliament and the Economic and Social Committee, even though there is a clear need for the JRC's budgetary requirements for 1977 to be entered into the budget for the coming financial year. The European Parliament is being urged to deliver its opinion no later than its part-session in September, which is about the time when the Finance Ministers are expected to be reaching more concrete budgetary decisions.

The Commission's proposed programme represents the outcome of many months of behind-the-scenes deliberation, including broad consultation with research and administrative staff. Last October the Commission sent to the Council its "Overall Concept" for the programme, setting out guidelines for the JRC's future role, and this the Council discussed at an inconclusive December meeting along with a document on a joint research and development policy. Other discussions took place in February, and the General Advisory Committee considered the draft programme in March and the Scientific and Technical Committee considered it in April.

The Commission has already stated that in framing the new programme it took into account "criticism made in where" that the JRC "had engaged in too many 'half-baked' projects which it had not the resources to complete" -criticism which arose, it said, "in part from the failure of the member effective guidelines".

Details of the final proposals now under consideration are shown in the accompanying table, but do not include the installation of the JET fusion project, which the Commission wants at Ispra, since a decision on the matter is still awaited.

In its final proposals the Commission points out, some would say rather obviously, that among the the European Parliament and elsestates to provide the Centre with guiding principles of the programme, primary consideration was given to the Community's interests in science and technology. From its discussion of these principles and of the JRC's role, however, a few important points emerge, namely, the priority being accorded to energy and environment questions, the stress on a Community public service role for the JRC (that is, making equipment, know-how, products and services available), and the concentration of activities and research potential on a small number of projects. There is also emphasis on the "rolling plan" character of the proposed programme, and on management and staff aspects.

The three-year rolling system, proposed in order to allow a greater degree of adaptability, is quite simple. The four-year programme would be submitted during the third year, when the Council would adopt a new fouryear programme in which the last year of the initial programme would become the first year of the new programme. The new programme would itself be submitted for revision during its third year, when a decision would be taken on the following programme. In the absence of decisions, current programmes would be continued according to the Council's original decisions.

Regarding the financial requirement over the forthcoming four-year period of 374.4 million units of account ( $£ 156$ million), the Commission says the pattern of investment expenditure envisaged means in practice that it will not 